DOI 10.15290/cnisk.2016.01.01.07

DR BEATA GOWORKO-SKŁADANEK

Uniwersytet $w$ Białymstoku

\title{
Obraz rosyjskich kobiet w życiu publicznym i politycznym na tle ogólnorosyjskich sondaży przeprowadzonych przez Levadę i VCIOM w latach 2005-2016
}

\begin{abstract}
Streszczenie
Zasada równości kobiet i mężczyzn pojawiła się w radzieckiej materii konstytucyjnej jeszcze przed druga wojna światową. Po raz pierwszy formalnie została ona zwerbalizowana w Konstytucji sowieckiej z 1936 r. Obecna Konstytucja FR z 1993 r. gwarantuje mężczyznom i kobietom równe prawa i wolności oraz równe możliwości ich realizacji. Mimo gwarancji konstytucyjnych równości praw i szans, Rosjanki wciąż uważaja się za pokrzywdzone, jeżeli chodzi o możliwość korzystania $z$ tego uprawnienia w życiu politycznym. Badania Levady z 2016 r. pokazuja, że $77 \%$ Rosjan uważało, że kobiety powinny być obecne w polityce, a 34\% widziałoby w ciagu najbliższych 10-15 lat kobietę pełniąca urząd prezydenta. Natomiast sondaż VCIOM pokazał, że od 2006 r. do 2015 r. wzrósł do 74\% odsetek Rosjan, którzy uważaja, że kobiety maja równe prawa $z$ mężczyznami.

Słowa kluczowe: Ogólnorosyjskie sondaże • sowiecka Konstytucja z 1936 r. • Konstytucja FR z 1993 r. • równość między kobietami i mężczyznami $\bullet$ udział kobiet w polityce
\end{abstract}




\title{
RUSSIAN WOMEN IN PUBLIC AND POLITICAL LIFE IN ALL-RUSSIAN SURVEYS CONDUCTED BY THE LEVADA AND VCIOM IN 2005-2016
}

\begin{abstract}
The principle of equality between women and men appeared in the Soviet constitutional matter before World War II. For the first time it was formally verbalized in the Soviet Constitution of 1936. The current FR Constitution of 1993 guarantees men and women equal rights and freedoms, equal opportunities for their implementation. Despite constitutional guarantees of equal rights and opportunities, Russian women are still dissatisfied, when it comes to the ability to use that power in political life. The Levada survey of 2016 shows that $77 \%$ of Russians think that women should be present in politics, and $34 \%$ would see a woman as a president over the next 10-15 years. VCIOM poll showed that from 2006 to 2015 the percentage of Russians who believe that women have equal rights with men increased to $74 \%$.

Keywords: All-Russian surveys - the Soviet Constitution of 1936 • FR Constitution of 1993 • equality between women and men • women's political participation
\end{abstract}

Zasada równości kobiet i mężczyzn pojawiła się w radzieckiej materii konstytucyjnej jeszcze przed druga wojna światowa. Pierwsza Konstytucja Rosyjskiej Federacyjnej Socjalistycznej Republiki Radzieckiej okresu sowieckiego z 1918 r. wzmocniła prawna równość kobiet i mężczyzn ${ }^{1}$. Było to odzwierciedleniem zwycięstwa rewolucji proletariackiej. W duchu koncepcji proletariackiego państwa, mężczyznom i kobietom przyznano taki sam status, stali się równi, ponieważ byli pracownikami lub zgodnie $z$ art. 7 Konstytucji z 1918 r. - masami pracujacymi ("трудящимися массами")2. Konstytucja z 1918 r. nie zwerbalizowała bezpośrednio zasady równości kobiet i mężczyzn. Nastapiło to dopie-

1 Kwestia równości mężczyzn i kobiet została uregulowana za pośrednictwem dekretów dotyczących równości mężczyzn i kobiet oraz małżeństwa cywilnego ze stycznia $1917 \mathrm{r}$.

2 L. N. Zavadskajâ, Razvitie konstitucionnoj idei ravenstvapolov v Konstituciâh SSSR 1918, glava 2. 1918, 1936 u 1977 gg. Gendernajâ èkspertiza rossijskogo zakonodatel'stua, [Dostęp: 01.07.2016]. Dostępny w World Wide Web: $<$ http://bit.ly/2g7LzKI>. 
ro w Konstytucji z 1936 r. ${ }^{3}$, w której w art. 122 zd. 1 zapisano, że Kobietom $w$ ZSRR przyznaje się równe prawa $z$ mężcyznami we wszystkich sferach: gospodarczej, stanu, kulturowej, społecznej $i \dot{z} y c i a$ politycznego. Kobiety na gruncie konstytucji uzyskały równe prawa co mężczyźni do pracy, wynagrodzenia, urlopu, ubezpieczenia społecznego, edukacji, ochrony państwa, urlopu macierzyńskiego $z$ pełnym wynagrodzeniem, korzystania $z$ szerokiej sieci domów dla matek, żłobków i przedszkoli.

Artykuł 35 Konstytucji ZSRR z 1977 r. ${ }^{4}$ jest dwuczłonowy. $Z$ pierwszego członu wypływa zasada równości płci: Kobiety i mężczyźni maja równe prawa $w$ ZSRR. Zaś w drugim członie zawarte zostały gwarancje mające przyczynić się do urzeczywistnienia równości płci. W pierwszej kolejności zostały wymienione pola, na których kobietom zapewnia się równe szanse, tj. w dostępie do edukacji i szkoleń, pracy, wynagrodzeń i awansu oraz w działaniach społecznych, politycznych i kulturalnych. W drugiej kolejności mowa jest o specjalnych środkach bezpieczeństwa i ochrony zdrowia kobiet, w tym ochrony prawnej, wsparcia materialnego i moralnego dla matek oraz dzieci, w tym płatnych urlopów i innych świadczeń dla kobiet w ciąży i matek oraz stopniowe ograniczanie czasu pracy dla matek $z$ małymi dziećmi.

W obecnie obowiąujacej Konstytucji Federacji Rosyjskiej z 1993 r. w art. 19 ust. 3 czytamy, że Mężczyzna i kobieta maja równe prawa i wolności oraz równe możliwości ich realizacji ${ }^{5}$. Zapis ten odpowiada treści norm prawa międzynarodowego ${ }^{6}$.

3 Konstituciâ (Osnovnoj zakon) Sojûza Sovetskich Socialističeskih Respublik (utverždena postanovleniem Crezvyčajnogo VIII Siezda Sovetov Soûza Sovetskih Socialističeskich Respublik ot 5 dekabrâ 1936 g.), [Dostęp: 17.05.2016]. Dostępny w World Wide Web: <http://bit.ly/2eUEUSi>.

4 Konstituciâ (Osnovnoj zakon) Sojûza Sovetskich Socialističeskich Respublik (prinâta na vneočerednoj sed'moj sessii Verhovnogo Soveta SSSR dieviâtogo sozyva 7 oktâbrâ 1977 g.) (s izmeneniâmi i dopolneniâmi - prekratila dejstvie), [Dostęp: 16.05.2016]. Dostępny w World Wide Web: <http://bit.ly/2eUyiHK>.

5 NPP „Garant-Servis", Konstituciâ Rossijskoj Federacii (prinâta na vsenarodnom golosovanii 12 dekabrâ 1993 g.) (s popravkami), [Dostęp: 16.05.2016]. Dostępny w World Wide Web: <http://bit.ly/2fNbJyi>.

6 W komentarzach do art. 19 ust. 3 Konstytucii FR przywoływane sa następujace przepisy: art. 3 Międzynarodowego Paktu Praw Obywatelskich i Politycznych (tekst, tj. art. 3 Międzynarodowego Paktu Praw Obywatelskich i Politycznych, Dz. U. z 1977 r. Nr 38, poz. 167); Konwencia w sprawie likwidacji wszelkich form dys- 
Chociaż odwołanie do płci pojawia się już w ust. 2 tego artykułu: Państwo gwarantuje równość praw i wolności człowieka i obywatela niezależnie od ptci (...), to wyraźne wzmocnienie tychże słów odnajdujemy w cytowanym ust. 3 art. 19. Takie ujęcie wskazuje na to, że kwestia poszanowania praw kobiet jest niezależnym przedmiotem regulacji konstytucyjnej, jednocześnie pozostajac $\mathrm{w}$ ścisłym zwiąku $\mathrm{z}$ pozostałymi prawami i wolnościami zagwarantowanymi $\mathrm{w}$ ramach systemu konstytucyjnego ${ }^{7}$. Dodatkowe gwarancje zostały zawarte w art. 38 ust. 1, z którego wynika, że Macierzyństwo, dzieci i rodzina znajduja sie pod ochrona państwa. Rozwinięciem przyjętej zasady równości sa przepisy, dotyczace wsparcia materialnego i moralnego, matek i dzieci oraz te, odwołujace się do pracy, zdrowia i emerytur kobiet.

Obecny kształt art. 19 ust. 3 obowiąującej Konstytucji z 1993 r. jest wynikiem aktywnych działań podejmowanych przez wiele organizacji kobiecych. Treść art. 35 zd. 1 Konstytucji z 1977 r. została wzbogacona o zapis odnoszący się do zapewnienia kobietom równych szans realizacji przyznanych praw. Zapis ten obecnie ma fundamentalne znaczenie, ponieważ tworzy konstytucyjna podstawę ochrony zarówno indywidualnych praw mężczyzn i kobiet, jak także ich praw zbiorowych, co jest zgodne $z$ trendami w rozwoju prawa międzynarodowego i prawa krajowego w demokratycznych państwach prawnych 8 .

W czasach sowieckich, gdy była głoszona formalna równość mężczyzn i kobiet, mimo że kobiety były reprezentowane we wszystkich strukturach władzy (w okresie działalności Rady Najwyższej ZSRR udział kobiet w 1952 r. wynosił 26\%, w 1970 r. -

kryminacji kobiet przyjęta przez Zgromadzenie Ogólne Narodów Zjednoczonych dnia 18 grudnia 1979 r. (Dz. U. z 1982 r. Nr 10, poz. 71); Konwencja MOP Nr 156 dotycząca równości szans i traktowania pracowników obu płci: pracowników majacych obowiazki rodzinne z 1981 r.; art. 14 Konwencji o Ochronie Praw Człowieka i Podstawowych Wolności sporządzona w Rzymie, 4 listopada 1950 r.

7 Konstituciâ RF, Poslednâjâ dejstvujûŝajâ redakciâ s Kommentariâmi, Stat'â 19 Konstitucii RF, [Dostęp: 16.05.2016]. Dostępny w World Wide Web: $<$ http://constrf.ru/razdel-1/glava-2/st-19-krf>.

8 Mužčina $i$ žensina imejût ravnye prava $i$ svobody $i$ ravnye vozmožnosti dlâ ich realizacii, [Dostęp: 09.03.2015]. Dostępny w World Wide Web: <http:// mydocx.ru/5-92686.html>. 
$31 \%^{9}$, a w 1984 r. - 32,8\%10), pozostawały one na marginesie realnej polityki11. Obecnie, mimo gwarancji konstytucyjnych równości praw i szans dla obywateli obu płci, Rosjanki wciąż uważaja się za pokrzywdzone, jeżeli chodzi o możliwość korzystania $z$ tego uprawnienia w prawdziwym życiu, zwłaszcza w społecznej i politycznej sferze na najwyższych szczeblach władzy ${ }^{12}$. Co widać najlepiej na przykładzie Dumy Państwowej Federacji Rosyjskiej, w której począwszy od 1993 r. odsetek zasiadajacych kobiet nie jest zbytnio wysoki (Tabela 1).

Tabela 1. Udział kobiet w I-VI kadencji Dumy Państwowej Federacji Rosyjskiej ${ }^{13}$

\begin{tabular}{|c|c|c|c|c|}
\hline \multirow{2}{*}{$\begin{array}{c}\text { Kadencja } \\
\text { Dumy } \\
\text { Państwowej }\end{array}$} & Okres & \multicolumn{3}{|c|}{ Udzial kobiet w Dumie Państwowej } \\
\cline { 3 - 5 } & & \%* & Lb. & $\begin{array}{c}\text { Wszyscy deputowani zasiadajacy } \\
\text { w Dumie Panstwowej w okresie } \\
\text { trwania kadencji }\end{array}$ \\
\hline I & $1993-1996$ & 12,87 & 60 & 466 \\
\hline II & $1996-1999$ & 6,92 & 34 & 491 \\
\hline III & $2000-2003$ & 7,13 & 34 & 477 \\
\hline IV & $2004-2007$ & 8,4 & 40 & 476 \\
\hline V & $2008-2011$ & 15,01 & 74 & 493 \\
\hline VI & $2012-$ & 13,39 & 60 & 448 \\
\hline
\end{tabular}

* Odsetek kobiet zasiadajacych w Dumie Państwowej w stosunku do wszystkich deputowanych, w czasie trwania kadencji. Źródło: Opracowanie własne ${ }^{14}$.

9 T. A. Koroleva, Problema učastiâ ženŝin v vybornom processe, „Srednerusskij vestnik obŝestvennyh nauk” 2013, No. 1, s. 97, [Dostęp: 16.05.2016]. Dostępny w World Wide Web: <http://bit.ly/2fJSGGk>.

10 A. Popova, Rossii neobhodimo bol'še ženŝin-liderov v politike: počemu?, [Dostęp: 13.01.2016]. Dostępny w World Wide Web: <http://bit.ly/2eQhgmL>.

11 A. V. Petrov, U.V. Kokoreva, Predstavitel'stvo ženŝin vo vlastnyh strukturah rossijskogo obŝestva: problemy i praktiki, „Sociologiâ i social'naâ rabota, Vestnik Nižegorodskogo universiteta im. N.I. Lobačevskogo. Seriâ Social'nye nauki”, 2007, No. 3 (8), s. 100, [Dostęp: 07.06.2016]. Dostępny w World Wide Web: $<$ http://bit.ly/2fPqUbU>.

12 N. Dorofeev, Prekrasnaâ polovina rossijskoj politiki, „Žurnal - Rossijskaâ Federaciâ segodnâ" 2013, No. 4, [Dostęp: 07.06.2016]. Dostępny w World Wide Web: <http://bit.ly/2euuiLi>.

13 A. M. Peršina, Žensiny-deputaty $v$ sostave Gosudarstvennoj Dumy federal'nogo sobraniâ IV sozyva (2004-2007 gody), „Vestnik” 2009, No. 3, s. 124, [Dostęp: 17.05.2016]. Dostępny w World Wide Web: <http://bit.ly/2eulo0x>.

14 Gosudarstvennajâ Duma Federal'nogo Sobraniâ Rossijskoj Federacii, Sostav Gosudarstvennoj Dumy pervogo sozyva (1993-1995), [Dostęp: 17.05.2016]. Do- 
Opinie Rosjan o przedmiocie udziału kobiet w strukturach władzy i życiu publicznym najlepiej odzwierciedlają sondaże przeprowadzane w latach 2005-2016 przez dwa centra badań opinii publicznej - VCIOM ${ }^{15}$ oraz Centrum-Levadę ${ }^{16}$.

Badanie przeprowadzone w 2016 r. przez Levadę pokazało, że $77 \%$ Rosjan uważało, że kobiety powinny być obecne w polityce (w 2014 r. - 68\%). Za taka opcja opowiedziało się 66\% mężczyzn (w 2014 r. $-53 \% 17$, a w 2012 r. $-64 \% 18$ ) i $86 \%$ kobiet $^{19}$ (w 2014 r. - 82\% ${ }^{20}$, a w 2012 r. $-84 \%^{21}$ ) (Tabela 2). Za w pełni równymi prawami kobiet i mężczyzn opowiedziało się $51 \%$ mężczyzn i $75 \%$ kobiet. Kwestia zrównania praw i obecności kobiet w polityce jest dla mężczyzn zdecydowanie mniej ważna niż dla samych kobiet. Autorzy raportu Seksizm na co dzień: Czy istnieje równość plci $w$ Rosji podejrzewaja, że mężczyźni mają ukryty interes w utrzymaniu asymetrii płci22.

stępny w World Wide Web: <http://bit.ly/2fPpE8J>; Sostav Gosudarstvennoj Dumy vtorogo sozyva (1996-1999), [Dostęp: 17.05.2016]. Dostępny w World Wide Web: <http://bit.ly/2g3ks4y>; Sostav Gosudarstvennoj Dumy tret'ego sozyva (2000-2003), [Dostęp: 17.05.2016]. Dostępny w World Wide Web: <http://bit.ly/2eUGOST>; Sostav Gosudarstvennoj Dumy četvertogo sozyva (2004-2007), [Dostęp: 17.05.2016]. Dostępny w World Wide Web: <http://bit.ly/2eQ14EH>; Sostav Gosudarstvennoj Dumy piâtogo sozyva (20082011), [Dostęp: 17.05.2016]. Dostępny w World Wide Web: <http://bit.ly/2fomOZy>; Sostav Gosudarstvennoj Dumy šestogo sozyva, [Dostęp: 17.05.2016]. Dostępny w World Wide Web: <http://bit.ly/2fJSOAx>.

15 Vserossijskij centr izučeniâ obŝestvennogo mneniâ (VCIOM), Istoriâ VCIOM, [Dostęp: 07.06.2016]. Dostępny w World Wide Web: <http://bit.ly/2g3qNwR>.

16 "Analitičeskij Centr Juriâ Levady" (Levada-Centr). Levada-Centr. O centre. Istoriâ, [Dostęp: 07.06.2016]. Dostępny w World Wide Web: $<$ http://bit.ly/2fwccWd $>$.

17 Levada-Centr, Učastie ženŝin $v$ politike, [Dostęp: 07.03.2014]. Dostępny w World Wide Web: <http://bit.ly/2g3vZRl>.

18 Idem, 8 marta, [Dostęp: 06.03.2012]. Dostępny w World Wide Web: <http://bit.ly/2fJRMtf>.

${ }^{19}$ Idem, Meždunarodnyj ženskij den' i gendernoe ravnopravie, [Dostęp: 04.03.2016]. Dostępny w World Wide Web: <http://bit.ly/ 2euoRw4>.

20 Idem, Učastie ženŝin v politike..., op. cit., [Dostęp: 07.03.2014]. Dostępny w World Wide Web: <http://bit.ly/2g3vZRl>.

${ }^{21}$ Idem, 8 marta..., op. cit., [Dostęp: 06.03.2012]. Dostępny w World Wide Web: $<$ http:// bit.ly/2fJRMtf>.

22 Idem, Obydennyj seksizm: Susestvuet li v Rossii ravnopravie polov, [Dostęp: 13.04.2016]. Dostępny w World Wide Web: <http://bit.ly/2eQnOSv>. 
Tabela 2. Opinie Rosjan, co do tego, czy kobiety powinny uczestniczyć w życiu politycznym (\%)

\begin{tabular}{|c|c|c|c|c|c|c|}
\hline Data badania: & 01.2006 & 02.2008 & 02.2012 & 02.2013 & 02.2014 & 02.2016 \\
\hline Zdecydowanie tak & 40 & 30 & 22 & 29 & 17 & 24 \\
\hline Raczej tak & 35 & 39 & 53 & 46 & 51 & 53 \\
\hline Raczej nie & 15 & 17 & 17 & 16 & 20 & 14 \\
\hline Zdecydowanie nie & 5 & 6 & 4 & 5 & 5 & 6 \\
\hline $\begin{array}{c}\text { Trudno } \\
\text { odpowiedzieć }\end{array}$ & 5 & 9 & 4 & 4 & 6 & 4 \\
\hline
\end{tabular}

Źródło: Levada-Centr, Mjeżdunarodnyj żjenskij djeń $i$ gjenjernoje rawnoprawije, [Dostęp: 04.03.2016]. Dostępny w World Wide Web: <http://bit.ly/ 2euoRw4>.

Podejrzenie o celowe utrzymywanie asymetrii płci wzmacniają dane dotyczace odpowiedzi na pytanie o to, czy jest to konieczne, aby kobiety zajmowały wysokie stanowiska rządowe na równi $z$ mężczyznami. Za takim stanem rzeczy opowiedziało się w 2016 r. ${ }^{23}$ - 50\% mężczyzn (w 2014 r. - 45\% ${ }^{24}$, a w 2012 r. $57 \%{ }^{25}$ ) i $78 \%$ kobiet (w 2014 r. $-79 \%{ }^{26}$, a w 2012 r. $-82 \%{ }^{27}$ ) (Tabela 3). Oznacza to, że w sumie $64 \%$ Rosjan chciałoby, aby kobiety pełniły ważne stanowiska $\mathrm{w}$ rządzie na równi $\mathrm{z}$ mężczyznami. Badacze Levady uważaja, że otrzymane wyniki przemawiaja za obecnością odwiecznego konfliktu między pierwiastkiem żeńskim a męskim, tkwiącym w samej naturze, który przekłada się na konflikt we współczesnej kulturze 28 .

23 Idem, Meždunarodnyj ženskij den'..., op. cit., [Dostęp: 04.03.2016]. Dostępny w World Wide Web: <http://bit.ly/2euoRw4>.

24 Idem, Učastie žensin v politike..., op. cit., [Dostęp: 07.03.2014]. Dostępny w World Wide Web: <http://bit.ly/2g3vZRl>.

25 AeBaga-UeHTp, 8 marta..., op. cit., Dostępny w World Wide Web: $<$ http://bit.ly/2fJRMtf>.

26 AeBaga-IIeHTp, Učastie ženŝin v politike..., op. cit., [Dostęp: 07.03.2014]. Dostępny w World Wide Web: <http://bit.ly/2g3vZRl>.

27 AeBaga-IJeHTp, 8 marta, op. cit., Dostępny w World Wide Web: $<$ http:/ / bit.ly/2fJRMtf $>$.

28 Lavada-Centr, Obydennyj seksizm..., op. cit., Dostęp: 13.04.2016]. Dostępny w World Wide Web: <http://bit.ly/2eQnOSv>. 
Tabela 3. Opinie Rosjan, co do tego, czy kobiety powinny zajmować wysokie stanowiska $\mathrm{w}$ rządzie, na równi z mężczyznami (\%).

\begin{tabular}{|c|c|c|c|c|c|c|}
\hline Data badania: & 01.2006 & 02.2008 & 02.2012 & 02.2013 & 02.2014 & 02.2016 \\
\hline Zdecydowanie tak & 35 & 27 & 21 & 26 & 15 & 18 \\
\hline Raczej tak & 35 & 37 & 49 & 40 & 48 & 46 \\
\hline Raczej nie & 16 & 20 & 17 & 21 & 22 & 20 \\
\hline Zdecydowanie nie & 8 & 8 & 7 & 7 & 7 & 8 \\
\hline $\begin{array}{c}\text { Trudno } \\
\text { odpowiedziec }\end{array}$ & 6 & 9 & 5 & 6 & 8 & 7 \\
\hline
\end{tabular}

Źródło: Levada-Centr, Meždunarodnyj ženskij den' i gendernoe ravnopravie, [Dostęp: 04.03.2016]. Dostępny w World Wide Web: <http://bit.ly/2euoRw4>.

34\% Rosjan badanych przez Levadę w 2016 r. widziałoby w ciagu najbliższych 10-15 lat kobietę pełniacac urząd prezydenta. Dwukrotnie więcej kobiet (44\%) niż mężczyzn (21\%) opowiada się za taka ewentualnością29. Przy czym od 2008 r. odnotowuje się coraz mniej zwolenników takiego stanu rzeczy przede wszystkim wśród mężczyzn (spadek o 10 p.p.) ${ }^{30}$.

Zdaniem Leonida Gutkowa, pierwiastek żeński gwarantuje więcej wolności, równości, daje większe możliwości na dyskusję polityczną i wymianę poglądów między różnymi opcjami politycznymi. Dlatego też zwiększenie poparcia dla udziału kobiet w polityce jest wynikiem niezadowolenia $z$ obecnej polityki Rosji. Uważa się, że kobiety sa w większym stopniu tolerancyjne, mniej agresywne i cyniczne. $Z$ drugiej strony Irina Chakamada, bioraca udział w wyborach prezydenckich w 2004 r. podała, że obecnie nie chciałaby uczestniczyć ponownie w kampanii wyborczej, ponieważ prezydentura nie jest urzędem dla kobiet, nie maja one także żadnych szans na wygraną31.

29 Idem, Meždunarodnyj ženskij den'..., op. cit., [Dostęp: 04.03.2016]. Dostępny w World Wide Web: <http://bit.ly/2euoRw4>.

30 Idem, Žensiny $v$ politike, [Dostęp: 05.03.2008]. Dostępny w World Wide Web: $<$ http://bit.ly/2f5RYSJ>.

31 O. Volkova, Rossiânam ne chvataet žensin v politike, [Dostęp: 03.07.2013]. Dostępny w World Wide Web: <http://bit.ly/2euqMki>. 
Tabela 4. Opinie Rosjan, co do tego, czy widzieliby w ciagu najbliższych 10-15 lat kobietę pełniąca urząd prezydenta (\%)

\begin{tabular}{|c|c|c|c|c|c|c|}
\hline Data badania: & 01.2006 & 02.2008 & 02.2012 & 02.2013 & 02.2014 & 02.2016 \\
\hline Zdecydowanie tak & 21 & 17 & 14 & 16 & 12 & 12 \\
\hline Raczej tak & 24 & 24 & 31 & 27 & 32 & 22 \\
\hline Raczej nie & 26 & 24 & 25 & 26 & 28 & 29 \\
\hline Zdecydowanie nie & 19 & 20 & 17 & 13 & 14 & 20 \\
\hline $\begin{array}{c}\text { Trudno odpowie- } \\
\text { dzieć }\end{array}$ & 11 & 16 & 13 & 18 & 14 & 18 \\
\hline
\end{tabular}

Źródło: Levada-Centr, Meždunarodnyj ženskij den' i gendernoe ravnopravie, [Dostęp: 04.03.2016]. Dostępny w World Wide Web: <http://bit.ly/2euoRw4>.

Badanie przeprowadzone przez VCIOM pokazało, że stosunek Rosjan do obecności kobiet $\mathrm{w}$ polityce na przestrzeni 13 lat (1998-2011) uległ ochłodzeniu. W 2011 r. prawie jedna czwarta badanych uważała, że liczba pań w polityce powinna być mniejsza lub nie powinno ich być w ogóle. W 1998 r., 45\% respondentów podało, że kobiety powinny być reprezentowane w polityce w zdecydowanie szerszym zakresie. W 2011 r. tego zdania było tylko $37 \%$, a $14 \%$ uznało, że kobiet $\mathrm{w}$ polityce jest zbyt dużo i chciałoby, aby usunąc je $z$ polityki (w 1998 r. - tylko 9\%). Mimo to połowa respondentów (50\%) popierała ideę reprezentacji kwotowej kobiet, zagwarantowanej prawnie. 19\% aprobowało to na pewno, a 31\% - raczej nie pochwalało. W 2005 r. pomysł ten znalazł zrozumienie u 44\% Rosjan32. Zauważyć należy, że w 2005 r., w okresie gorącej dyskusji nad kwotowa reprezentacja kobiet w strukturach władzy, prawie co czwarty badany Rosjanin uważał, że zarówno w Dumie Państwowej, jak i w rządzie, powinno zasiadać nie mniej niż 25\% kobiet. Najwięcej zwolenników takiego rozwiązania było wśród kobiet. Biorąc pod uwagę płeć respondentów, należy zauważyć, że więcej mężczyzn niż kobiet opowiedziało się za przyznaniem kobietom nie więcej niż 10\% miejsc w Dumie i rządzie. Jednak najwięcej osób odpowiedziało, że stosunek męż-

32 VCIOM, Ženŝin $v$ politike byt' ne dolžno, [Dostęp: 26.07.2011]. Dostępny w World Wide Web: <http://bit.ly/2fNibFF>. 
czyzn i kobiet, zasiadających w organach władzy jest dla nich bez znaczenia $(28 \%)^{33}$.

Od 2006 r. (48\%) do 2015 r. (74\%) wzrosła o połowę liczba Rosjan, którzy uważaja, że kobiety mają równe prawa $z$ mężczyznami. Zmniejszyła się także ponad dwukrotnie liczba osób, które uważały, że to mężczyźni mają więcej praw niż kobiety (z $44 \%$ w 2006 r. do 19\% w 2015 r.). Osób, które uważaja, że kobiety maja więcej praw niż mężczyźni zarówno w 2006 r., jak i w 2015 r. było tyle samo $(2 \%)^{34}$.

Przeprowadzony w 2016 r. sondaż przez VCIOM z okazji Dnia Kobiet pokazał, że największą popularnością cieszy się wśród kobiet polityków i osób publicznych Walentina Matwiejenko (34\% wskazań w 2016 r. oraz 26\% w 2002 r.) oraz Irina Chakamada (6\% w 2016 r. i 30\% w 2002 r.). W tym samym sondażu za symbol współczesnej Rosji zostały uznane Walentina Matwiejenko (5\%), Walentina Tierieszkowa (4\%), Ałła Pugaczowa (3\%) i Irina Chakamada $(2 \%)^{35}$.

W rankingu najbardziej wpływowych kobiet w Rosji „Echo Moskwy"36, od czterech lat pierwsze miejsce zajmuje Walentina Matwiejenko. Poza nia w pierwszej dziesiątce najbardziej wpływowych kobiet od 2012 r. pojawiaja się Elwira Nabiullina i Natalia Timakowa. W rankingu znajduja się głównie kobiety piastujące stanowiska polityczne. Poza nimi znalazły się tam także działaczki społeczne, redaktorki, dziennikarki, artystki, pisarki i sportsmenki.

33 Idem, Ženskij interes $v$ rossijskoj politike, Press-vypusk No. 356, [Dostęp: 12.12.2005]. Dostępny w World Wide Web: <http://bit.ly/2g7QTOI>.

34 Idem, Rawjenstwo połow $w$ Rossii: stało łuczszje!, Press-vypusk No. 2788, [Dostęp: 05.03.2015]. Dostępny w World Wide Web: <http://bit.ly/2eur8qZ>.

35 Idem, "Segodnâ v každom dele nam žensiiny pod stat'...", Press-vypusk No. 3052, [Dostęp: 03.03.2016]. Dostępny w World Wide Web: <http://bit.ly/ 2euvSNx>.

36 Ranking stworzony został przez analityków rozgłośni radiowej „Echo Moskwy”, agencji informacyjnych RIA Novosti, „Interfaks” i czasopisma "Ogoniok” w 2012 r. Głównym kryterium oceny, która wpływa na pozycję danej kobiety w rankingu, jest liczba wzmianek w mediach. Radio Głos Rosji, Najbardziej wpływowe kobiety Rosji, [Dostęp: 04.03.2013]. Dostępny w World Wide Web: <http:// bit.ly/2fORCUa>. 
Tabela 5. 10 najbardziej wpływowych kobiet w Rosji wg rankingu „Echo Moskwy"37

\begin{tabular}{|c|c|c|c|c|}
\hline \multirow{2}{*}{ Pozycja } & \multicolumn{4}{|c|}{ Data publikacji rankingu } \\
\hline & 2015 & 2014 & 2013 & 2012 \\
\hline 1. & $\begin{array}{c}\text { Waljentina } \\
\text { Matwjejenko }^{a}\end{array}$ & $\begin{array}{c}\text { Waljentina } \\
\text { Matwjejenko }^{a}\end{array}$ & $\begin{array}{c}\text { Waljentina } \\
\text { Matwjejenko }^{a}\end{array}$ & $\begin{array}{c}\text { Waljentina } \\
\text { Matwjejenko }\end{array}$ \\
\hline 2. & $\begin{array}{c}\text { Elwira } \\
\text { Nabiullina } \\
\end{array}$ & $\begin{array}{c}\text { Elwira } \\
\text { Nabiullina }^{\mathrm{b}} \\
\end{array}$ & $\begin{array}{c}\text { Olga } \\
\text { Gołodjec }^{c}\end{array}$ & $\begin{array}{c}\text { Ałła } \\
\text { Pugaczowak } \\
\end{array}$ \\
\hline 3. & $\begin{array}{c}\text { Olga } \\
\text { Gołodiec }^{c}\end{array}$ & $\begin{array}{c}\text { Tatiana } \\
\text { Golikowa }^{\mathrm{d}}\end{array}$ & $\begin{array}{c}\text { Natalia } \\
\text { Timakowa }\end{array}$ & $\begin{array}{c}\text { Natalia } \\
\text { Timakowa }\end{array}$ \\
\hline 4. & $\begin{array}{c}\text { Tatjana } \\
\text { Golikowa }^{\mathrm{d}}\end{array}$ & $\begin{array}{c}\text { Olga } \\
\text { Golodjec }\end{array}$ & $\begin{array}{c}\text { Elwira } \\
\text { Nabiullina }^{\mathrm{b}}\end{array}$ & $\begin{array}{c}\text { Swjetłana } \\
\text { Miedwiejewnam }^{\mathrm{m}}\end{array}$ \\
\hline 5. & $\begin{array}{c}\text { Alina } \\
\text { Kabajewa }\end{array}$ & $\begin{array}{c}\text { Larisa } \\
\text { Brychewag }\end{array}$ & $\begin{array}{c}\text { Ałła } \\
\text { Pugaczowak }^{k}\end{array}$ & $\begin{array}{c}\text { Elwira } \\
\text { Nabiullina }^{\mathrm{b}}\end{array}$ \\
\hline 6. & $\begin{array}{c}\text { Elizawjeta } \\
\text { Glinka }\end{array}$ & $\begin{array}{c}\text { Ałła } \\
\text { Pugaczowak }\end{array}$ & $\begin{array}{c}\text { Larisa } \\
\text { Brychewag }\end{array}$ & $\begin{array}{c}\text { Tatiana } \\
\text { Golikowa }^{\mathrm{d}}\end{array}$ \\
\hline
\end{tabular}

$37 \mathrm{~W}$ tabeli zostały zaprezentowane najbardziej wpływowe kobiety w Rosji, które zajęły pierwszych 10 miejsc. Cały ranking zawiera 100 pozycji. Zostały w nim ujęte:

a Przewodniczaca Rady Federacji, były gubernator Sankt-Petersburga.

b Szefowa Banku Centralnego.

c Wicepremier do spraw socjalnych.

d Prezes Izby Obrachunkowej Federacji Rosyjskiej.

e Gimnastyczka, mistrzyni olimpijska, osoba publiczna, przewodniczaca Rady Nadzorczej Rosyjskiej Spółki Medialnej "национальная медиа группа".

f dr Lisa, lekarz-resuscytator, dyrektor wykonawczy fundacji "справедливая помощь".

g Przewodniczaca Administracji Publicznej Prezydenta.

h Szefowa Federalnej Agencji Zarządzania Nieruchomościami.

i Inżynier i polityk, minister ds. opieki społecznej Rosji w latach 1991-1994, mąż stanu i osoba publiczna, Komisarz ds. Praw Człowieka w Federacji Rosyjskiej.

j Rzeczniczka premiera Dmitrija Miedwiedjewa.

k Piosenkarka, kompozytorka, artystka.

${ }^{1}$ Przewodnicząca Miejskiego Sądu Moskiewskiego.

m żona premiera Rosji Dmitrija Miedwiedjewa, szefowa Rady Nadzorczej Krajowego Programu „Kultura duchowa i moralna młodego pokolenia Rosji”.

n Aktorka teatralna i filmowa, jedna z założycieli fundacji „Podarować życie”, Redaktor naczelna RIA Novosti.

p Dziennikarka, prezenterka telewizyjna, córka pierwszego mera Petersburga Anatolija Sobczaka.

r Przewodnicząca Moskiewskiej Grupy Helsińskiej, członek Rady Prezydenta Federacji Rosyjskiej na rzecz Rozwoju Społeczeństwa Obywatelskiego i Praw Człowieka. 


\begin{tabular}{|c|c|c|c|c|}
\hline \multirow{2}{*}{ Pozycja } & \multicolumn{4}{|c|}{ Data publikacji rankingu } \\
\hline & 2015 & 2014 & 2013 & 2012 \\
\hline 7. & $\begin{array}{c}\text { Larisa } \\
\text { Brychewag }\end{array}$ & $\begin{array}{c}\text { Natalia } \\
\text { Timakowaj }\end{array}$ & $\begin{array}{c}\text { Olga } \\
\text { Jegorowa }\end{array}$ & $\begin{array}{c}\text { Ksenia } \\
\text { Sobczakp }\end{array}$ \\
\hline 8. & $\begin{array}{c}\text { Olga } \\
\text { Dergunowah }^{\mathrm{h}}\end{array}$ & $\begin{array}{c}\text { Alina } \\
\text { Kabajewa }\end{array}$ & $\begin{array}{c}\text { Swjetłana } \\
\text { Miedwiedjewna }^{m} \\
\end{array}$ & $\begin{array}{c}\text { Olga } \\
\text { Jegorowa }\end{array}$ \\
\hline 9. & $\begin{array}{c}\text { Ełła } \\
\text { Pamfiłowa }\end{array}$ & $\begin{array}{c}\text { Olga } \\
\text { Dergunowah }^{\mathrm{h}}\end{array}$ & $\begin{array}{c}\text { Czułpan } \\
\text { Chanatowa }^{\mathrm{n}}\end{array}$ & $\begin{array}{c}\text { Alina } \\
\text { Kabajewa }\end{array}$ \\
\hline 10. & $\begin{array}{c}\text { Natalia } \\
\text { Timakowai }\end{array}$ & $\begin{array}{c}\text { Olga } \\
\text { Jegorowa }\end{array}$ & $\begin{array}{l}\text { Swjetłana } \\
\text { Mironiuk }^{\circ} \\
\end{array}$ & $\begin{array}{c}\text { Ludmiła } \\
\text { Aleksjejewa }\end{array}$ \\
\hline
\end{tabular}

Źródło: opracowanie własne ${ }^{38}$.

Przedstawione sondaże, zwłaszcza Levady, pokazuja coraz większą otwartość Rosjan na obecność kobiet w życiu politycznym. Kobiety sa też coraz bardziej zauważalne na scenie politycznej, o czym świadczy ranking „Echo Moskwy” na najbardziej wpływową kobietę w Rosji, będacy odzwierciedleniem ich obecności w mediach. Kobiety sa aktywnymi uczestnikami życia politycznego w i $z$ zasady maja pełne prawa w sferze politycznej. Jednak, w większości przypadków zajmuja one stanowiska na niższych i średnich szczeblach struktur politycznych ${ }^{39}$. Co oznacza, że faktyczny udział kobiet w podejmowaniu decyzji politycznych jest $\mathrm{w}$ dalszym ciagu niezadowalajacy. W zwiazku $\mathrm{z}$ tym istnieje potrzeba wyeliminowania przede wszystkim barier formalnych. Jednak nie tylko one stoją na przeszkodzie zwiększenia udziału kobiet u władzy. Potrzebne sa także zmiany w mentalności społeczeństwa rosyjskiego, w którym w dalszym ciagu pokutuje myślenie, że polityka to nie miejsce dla kobiet.

38 Radiostanciâ "Ėcho Moskvy", 100 samych vliâtel'nyh žensîn Rossii-rejting, [Dostęp: 08.03.2015]. Dostępny w World Wide Web: <http://bit.ly/1ARFFTa>; Radiostanciâ "Ėcho Moskvy", 100 samych vliâtel'nyh ženŝin Rossii - rejting, [Dostęp: 03.03.2014]. Dostępny w World Wide Web: <http://bit.ly/2foqYAE>; Radiostanciâ "Ėcho Moskvy", 100 samych vliâtel'nyh ženŝin Rossii - rejting, [Dostęp: 04.03.2013]. Dostępny w World Wide Web: <http://bit.ly/2g7QKdw>; Radiostanciâ "Ėcho Moskvy", 100 samych vliâtel'nyh ženŝin Rossii-rejting, [Dostęp: 23.01.2012]. Dostępny w World Wide Web: <http://bit.ly/2euwjY9>.

39 A. Popova, op. cit., [Dostęp: 23.01.2012]. Dostępny w World Wide Web: http:// bit.ly/2eQhgmL>. 


\section{Bibliografia}

\section{Zasoby internetowe}

"Analitičeskij Centr Juriâ Levady" (Levada-Centr). Levada-Centr. O centre. Istoriâ, [Dostęp: 07.06.2016]. Dostępny w World Wide Web: <http: / / bit.ly/2fwccWd>.

Dorofeev N., Prekrasnaâ polovina rossijskoj politiki, „Žurnal - Rossijskaâ Federaciâ segodnâ" 2013, No. 4, [Dostęp: 07.06.2016]. Dostępny w World Wide Web: <http://bit.ly/2euuiLi>.

Gosudarstvennajâ Duma Federal'nogo Sobraniâ Rossijskoj Federacii, Sostav Gosudarstvennoj Dumy pervogo sozyva (1993-1995), [Dostęp: 17.05.2016]. Dostęny w World Wide Web: <http://bit.ly/2fPpE8J>.

Sostav Gosudarstvennoj Dumy vtorogo sozyva (1996-1999), [Dostęp: 17.05.2016]. Dostępny w World Wide Web: <http://bit.ly/2g3ks4y>.

Sostav Gosudarstvennoj Dumy tret'ego sozyva (2000-2003), [Dostęp: 17.05.2016]. Dostępny w World Wide Web: <http://bit.ly/2eUGOST>. Sostav Gosudarstvennoj Dumy četvertogo sozyva (2004-2007), [Dostęp: 17.05.2016]. Dostępny w World Wide Web: <http://bit.ly/2eQ14EH>. Sostav Gosudarstvennoj Dumy piâtogo sozyva (2008-2011), [Dostęp: 17.05.2016]. Dostępny w World Wide Web: <http://bit.ly/2fomOZy>. Sostav Gosudarstvennoj Dumy šestogo sozyva, [Dostęp: 17.05.2016].

Dostępny w World Wide Web: <http://bit.ly/2fJSOAx>.

Konstituciâ (Osnovnoj zakon) Sojûza Sovetskich Socialističeskih Respublik (utverždena postanovleniem Črezvyčajnogo VIII Siezda Sovetov Soûza Sovetskih Socialističeskich Respublik ot 5 dekabrâ 1936 g.), [Dostęp: 17.05.2016]. Dostępny w World Wide Web: <http:/ / bit.ly/2eUEUSi>.

Konstituciâ (Osnovnoj zakon) Sojûza Sovetskich Socialističeskich Respublik (prinâta na vneočerednoj sed'moj sessii Verhovnogo Soveta SSSR dieviâtogo sozyva 7 oktâbrâ 1977 g.) (s izmeneniâmi i dopolneniâmi - prekratila dejstvie), [Dostęp: 16.05.2016]. Dostępny w World Wide Web: <http://bit.ly/2eUyiHK>.

Konstituciâ RF, Poslednâjâ dejstvujûsajâ redakciâ s Kommentariâmi, Stat'â 19 Konstitucii RF, [Dostęp: 16.05.2016]. Dostępny w World Wide Web: <http://constrf.ru/razdel-1/glava-2/st-19-krf>.

Koroleva T.A., Problema učastiâ žensîn v vybornom processe, „Srednerusskij vestnik obŝestvennyh nauk” 2013, No. 1, s. 97, [Dostęp: 16.05.2016]. Dostęny w World Wide Web: <http://bit.ly/2fJSGGk>. Levada-Centr, 8 marta, [Dostęp: 06.03.2012]. Dostępny w World Wide Web: <http://bit.ly/2fJRMtf>. 
Levada-Centr, Obydennyj seksizm: Susestuuet li v Rossii ravnopravie polov, [Dostę: 13.04.2016]. Dostepny w World Wide Web: $<$ http:/ / bit.ly/2eQnOSv>.

Levada-Centr, Meždunarodnyj ženskij den' i gendernoe ravnopravie, [Dostępny: 04.03.2016]. [Dostęp: 07.03.2014]. Dostępny w World Wide Web: <http: / / bit.ly/2euoRw4>.

Levada-Centr, Učastie ženŝin v politike, [Dostęp: 07.03.2014]. Dostępny w World Wide Web: <http://bit.ly/2g3vZRl>.

Levada-Centr, Žensiny $v$ politike, [Dostęp: 07.03.2014]. Dostępny w World Wide Web: <http://bit.ly/2f5RYSJ>.

Mužčina $i$ žensina imejût ravnye prava $i$ svobody $i$ ravnye vozmožnosti dlâ ich realizacii, [Dostęp: 09.03.2015]. Dostępny w World Wide Web: <http:/ / mydocx.ru/5-92686.html>.

NPP „Garant-Servis”, Konstituciâ Rossijskoj Federacii (prinâta na vsenarodnom golosovanii 12 dekabrâ 1993 g.) (s popravkami), [Dostęp: 16.05.2016]. Dostępny w World Wide Web: <http://bit.ly/2fNbJyi>.

Peršina A. M., Žensiny-deputaty $v$ sostave Gosudarstvennoj Dumy federal'nogo sobraniâ IV sozyva (2004-2007 gody), „Vestnik” 2009, No. 3, s. 124, [Dostęp: 17.05.2016]. Dostępny w World Wide Web: $<$ http: / / bit.ly/2eulo0x>.

Petrov A. V., Kokoreva U.V., Predstavitel'stvo ženŝin vo vlastnyh strukturah rossijskogo obsestua: problemy i praktiki, „Sociologiâ i social'naâ rabota, Vestnik Nižegorodskogo universiteta im. N.I. Lobačevskogo. Seriâ Social'nye nauki”, 2007, No. 3 (8), s. 100, [Dostęp: 07.06.2016]. Dostępny w World Wide Web: <http://bit.ly/2fPqUbU>.

Popowa A., Rossii neobhodimo bol'še ženŝin-liderov v politike: počemu?, [Dostęp: 13.01.2016]. Dostępny w World Wide Web: <http://bit.ly/ 2eQhgmL>.

Radio Głos Rosji, Najbardziej wpływowe kobiety Rosji, [Dostęp: 04.03.2013]. Dostępny w World Wide Web: <http: //bit.ly/2fORCUa>.

Radiostanciâ "Ėcho Moskvy", 100 samych vliâtel'nyh žensiin Rossii - rejting, [Dostęp: 08.03.2015]. Dostępny w World Wide Web: <http:/ / bit.ly/ 1ARFFTa

Radiostanciâ "Ėcho Moskvy", 100 samych vliâtel'nyh žensìn Rossii - rejting, [Dostęp: 03.03.2014]. Dosteppny w World Wide Web: $<$ http:/ / bit.ly/2foqYAE>.

Radiostanciâ "Ėcho Moskvy", 100 samych vliâtel'nyh ženŝin Rossii- rejting, [Dostęp: 04.03.2013]. Dostępny w World Wide Web: $<$ http://bit.ly/2g7QKdw>. 
Radiostanciâ "Ėcho Moskvy", 100 samych vliâtel'nyh ženŝin Rossii - rejting, [Dostęp: 23.01.2012]. Dostępny w World Wide Web: <http://bit.ly/2euwjY9>.

Radiostancija "Echo Moskwy", 100 samych wlijatjelnych żjenszczin Rossii rjejting, [Dostęp: 23.01.2012]. Dostępny w World Wide Web: <http://bit.ly/2eu^Y9>.

Volkova O., Rossiânam ne chvataet ženŝin $v$ politike, [Dostęp: 03.07.2013]. Dostępny w World Wide Web: <http://bit.ly/2euqMki>.

Vserossijskij centr izučeniâ obŝestvennogo mneniâ (VCIOM), Istoriâ VCIOM, [Dostęp: 07.06.2016]. Dostępny w World Wide Web: $<$ http:/ / bit.ly/2g3qNwR>.

Vserossijskij centr izučeniâ obŝestvennogo mneniâ (VCIOM), Rawjenstwo połow w Rossii: stało łuczszje!, Press-vypusk No. 2788, [Dostęp: 05.03.2015]. Dostępny w World Wide Web: <http://bit.ly/2eur8qZ

Vserossijskij centr izučeniâ obŝestvennogo mneniâ (VCIOM), Segodnâ $v$ každom dele nam žensiny pod stat'...", Press-vypusk No. 3052, [Dostę: 03.03.2016]. Dostępny w World Wide Web: <http://bit.ly/2euvSNx>.

Vserossijskij centr izučeniâ obŝestvennogo mneniâ (VCIOM), Ženskij interes $v$ rossijskoj politike, Press-vypusk No. 356, [Dostęp: 12.12.2005]. Dostępny w World Wide Web: <http://bit.ly/2g7QTOI>.

Vserossijskij centr izučeniâ obŝestvennogo mneniâ (VCIOM), Ženŝin v politike byt' ne dolžno, [Dostęp: 26.07.2011]. Dostępny w World Wide Web: <http:// bit.ly/2fNibFF>.

Zavadskajâ L. N., Razvitie konstitucionnoj idei ravenstvapolov $v$ Konstituciâh SSSR 1918, glava 2. 1918, 1936 u 1977 gg. Gendernajâ èkspertiza rossijskogo zakonodatel'stva, [Dostęp: 01.07.2016]. Dostępny w World Wide Web: <http://bit.ly/2g7LzKI>. 